\title{
Die wonders in Johannes 6 verklaar aan die hand van 'n vertellersperspektiefanalise
}

\author{
GF Snyman
}

\begin{abstract}
The miracles in John 6: 1-21, explained in terms of an analysis of the narrator's perspective

The author of the Gospel of John reconstructed creatively, under the guidance of the Holy Spirit, certain events in the life of Jesus Christ. His description of these events does not amount to an accumulation of facts or to a literal description. Instead, the events are vividly described to the reader. What is told, seems to be enough to bring people to faith in Christ as the Messiah and to lead them to life (In 20: 30-31).

This effect is obtained by the author's interpretation, as can be seen by his use of a narrator who introduces the reader to the story using a peculiar device, namely the two-step progression. Hereby the reader is confronted with two miracles on the same subject: Only with Christ there is life! This is illustrated from two perspectives:

- the miracle of the feeding of the five thousand, as told from the perspective of Him who performed it, and

- the miracle of the walking on the waters, as told from the perspective of those who saw it, the disciples.
\end{abstract}

\section{INLEIDING}

Die gebruik van 'n metode soos die vertellersperspektiefanalise veronderstel ' $n$ paar metodologiese vooronderstellings met betrekking tot literêre vorm en geskiedenisbeskrywing. Die vorm geskiedenisbeskrywing dien nie maar net om die inhoudelike perspektief weer te gee nie, maar is ' $n$ wesenlike deel van die teks en dit dra by tot die uiteindelike verstaan van die teks. Met hierdie siening word daar aangesluit by die siening van Aristoteles in sy Ars Poetica (1449b en 1453b). By die 
vertellersperspektief gaan dit nie net om wat in die teks gesê word nie, maar ook om hoe dit gesê word.

Die wyse van geskiedenisbeskrywing is nie ' $n$ blote versameling van empiriese feite nie. Die manier waarop gebeure waargeneem word, verskil van die wyse waarop 'n natuurwetenskaplike dit doen (Collingwood 1978: 133). Laasgenoemde sal altyd onder dieselfde omstandighede dieselfde resultate verkry. Hy kan ook self hierdie omstandighede bepaal. ' $n$ Historikus kan nie die omstandighede self produseer nie en die gebeure wat hy beskryf, het net een keer gebeur. Waarmee hy te doen het, is nie die gebeure self nie, maar verklarings aangaande die gebeure. Hierdie verklarings is alleen 'n bevestiging dat ' $n$ bepaalde gebeurtenis werklik plaasgevind het (Becker 1970: 36).

Die plek van 'n gebeurtenis word na verloop daarvan ingeneem deur refleksies op die gebeurtenis (Becker 1970). Hierdie refleksies op bepaalde gebeure word, wat die antieke tyd betref, in sekere geskrifte gevind. In die moderne tyd word die refleksies eerder in koerante en op televisie gevind. Dit alles vorm 'n historikus se materiaal. In hierdie materiaal is dooie feite opgesluit wat op hulle eie niks kan doen nie. Die feite kry eers betekenis en lewe wanneer die historikus die gebeure begin konstrueer.

Die feite spreek nie sommer vanself nie (Becker 1970: 40). As dit vanself moes spreek, sou mens al die feite moes weergee. En dit is onmoontlik vanweë die mens se beperkte vermoë. Al wat hy kan doen, is om hipoteses te vorm met behulp van die beskikbare data (Brown 1976: 169). Omdat al die feite nie gebruik word nie, moet 'n mens aanvaar dat die historikus bepaalde keuses moes maak. Hy kan nooit neutraal teenoor die feite staan nie (Brown 1970: 179). Die keuse word op sy beurt bepaal deur die raamwerk waaruit die historikus meen om te werk.

Bogenoemde kan geillustreer word aan die hand van die volgende voorbeeld: Die volgende word as ' $n$ feit aanvaar:

'Amerika het Libië in die nag van 14 April met vliegtuie aangeval.'

Dit is 'n sogenaamde dooie feit. Dit verkry eers betekenis wanneer Amerika en Libië onderskeidelik die feit interpreteer. 'n Amerikaner sien hierdie aanval as 'n vergeldingstap teenoor Libië se volgehoue terreuraanslae waarin Amerikaanse burgers gedood word. Libië het in 
sy interpretasie van hierdie feit verswyg dat hy sekere terroristegroepe help om teen Amerika op te tree. Hulle beskou dit as 'n daad van staatsterrorisme en deel van die Amerikaanse imperialistiese drang. Hierdie verskil in benadering is te wyte aan die verskil in raamwerke. Amerika tree op omdat hulle meen dat die idee van 'n vrye wêreld deur Libië in gevaar gestel word. Libië beoog weer om vanuit 'n Moslemraamwerk, die Moslemrewolusie oor die hele aarde te versprei.

Die wyse waarop geskiedenis beskryf word, is in verhaalvorm (Pirenne 1970: 30). Dit is nie 'n blote opeenstapeling van feite nie. Hierdie feite het te doen met menslike handelinge in gegewe situasies. Ten einde hierdie feite lewe te gee, word dit in een geheel saamgebind binne 'n opeenvolging van verwante episodes (Pirenne 1970: 29) waarin mense optree. Omdat die historikus 'n beoordeling maak van die beskikbare feite en nie besig is om kos sonder enige geurmiddels op te kook en geurloos en onsmaaklik voor te sit nie, is hy skeppend besig. In hierdie sin kan gesê word dat geskiedskrywing ' $n$ bepaalde kunsvorm is wat volgens die riglyne van literêre benadering beoordeel kan word. Ten einde betekenis aan die feite te gee, skep hy menslike intriges en boots hy die handelinge van mense na. Dit vorm uiteindelik die hipotese van hoe hy meen die feite aan mekaar skakel en wat hy dink die motiewe is wat agter bepaalde gebeure lê.

Dit is moontlik om die voorafgaande metodologiese vooronderstellings op die Evangelie volgens die beskrywing van Johannes, van toepassing te maak. Die skrywer het ten doel om sekere gebeurtenisse in die lewe van Jesus Christus uit te lig en te beskryf (Joh 20: 30-31). Die beskrywing is nie 'n opeenstapeling van dooie feite nie, maar die gebeure word lewend voor die leser se oog beskrywe. Sy bron is die getuienis van ' $n$ bepaalde dissipel (Joh 21: 24). Bepaalde gebeure word ook verder verklaar om sodoende 'n besondere betekenis daaraan te heg. Dit kan gesien word in die verhouding van teken en verkondiging van Jesus wat mekaar voortdurend afwissel. Maar ook in die beskrywing van die tekens is daar reeds ' $n$ verklarende kommentaar op die feite self te vinde byvoorbeeld Johannes 6: 6. Die skrywer van die Evangelie is skeppend besig; met behulp van die materiaal van die verlede soos uitdrukkings, weergawes en waarnemings rekonstrueer hy, onder leiding van die Heilige Gees, die gebeure. Die eindproduk is nie 'n letterlike beskrywing van die oorspronklike nie, maar dit is wel voldoende om tot geloof te bring en na die ewige lewe te lei (Joh 20: 30-31). 


\section{2. 'N VERGELYKING MET DIE SINOPTIESE EVANGELIES}

\subsection{Die sinoptiese vraagstuk}

Die weergawe van die vermeerdering van die brode en die seewandeling in Johannes 6: 1-21 verskil in verskeie opsigte van díe in die Sinoptiese Evangelies. Wat die vraagstuk verder kompliseer, is dat die Evangelies van Lukas en Johannes net een vermeerdering berig, terwyl die Evangelies van Matteus en Markus van twee vermeerderings berig (Matt 15: 29-38 en Mark 8: 1-19). Die Johannesevangelie blyk boonop met beide weergawes ooreenkomste te hê!

Versteeg (1980: 97-99) meld vyf soorte verskille tussen die Evangelie van Johannes en die Sinoptiese Evangelies:

- beskrywing van Jesus se optrede

In die Evangelie van Johannes is Jesus 'n teenswoordige realiteit waarvan die beslissende reeds in sy aardse optrede aangebreek het, terwyl die sinoptici die aardse lewe van Jesus in 'n toekomslig sien.

- beskrywing van Jesus se wonders

Die Johannesevangelie beskryf wonders wat nie in die Sinoptiese Evangelies voorkom nie. Daar word minder op genesingswonders klem gelê en geen duiweluitdrywings word gemeld nie.

- beskrywing van Jesus se woorde

In die Vierde Evangelie word meer gesprekke van Jesus weergegee in teenstelling met die ander drie wat korter uiteensettinge gee. Die Johannesevangelie gee ook geen gelykenisse weer nie, maar steun weer op allegorieë.

- beskrywing van tyd en plek van Jesus se optrede

By die Vierde Evangelie neem Galilea as werksterrein 'n ondergeskikte plek in en is die eintlike werksterrein Judea. Hierteenoor is die belangrikste werksterrein van Jesus in die eerste drie Evangelies Galilea, terwyl die indruk gelaat word dat Jesus net voor die laaste Pasga Jerusalem toe gaan.

- beskrywing van Jesus as persoon

Ofskoon die Sinoptiese Evangelies die geskiedenis van Jesus as die van 'n mens sien, val die lig op sy goddelike heerlikheid. Die Evangelie van Johannes sien Jesus as 'n egte mens, maar vir díe geskrif is die goddelike Seunskap en Jesus as Messias die belangrikste.

Volgens Versteeg (1980: 102) blyk dit hieruit reeds dat die Vierde 
Evangelie 'n besondere plek het. Hy wil die verskille verantwoord deur dit aan ' $n$ bepaalde teologiese dimensie te koppel.

Coetzee (sj b: 33) sê die Redaktionsgeschichte het die aandag tereg geplaas op die Evangelies as literêre eenhede, asook op die besondere aard en boodskap van elke Evangelie. Ofskoon elke Evangelie oor die verkondiging van Christus handel (Du Toit 1980: 7), gee elke evangelis bepaalde fasette van hierdie verkondiging: Eie aksente word geplaas deurdat historiese feite en geloofsinterpretasie met mekaar verweef word.

Om die eie aksente van die Evangelie van Johannes te verklaar, moet gekyk word na die doel van die Evangelie. Van Aarde (1982: 59) maak van die sogenaamde 'intentional fallacy' melding. Dit is wanneer gepoog word om vanaf die teks sonder meer na die intensie van die skrywer te soek. Díe doel kan alleen verwesenlik word deur 'n ondersoek na die wyse waarop 'n skrywer sy werk vir sy lesers aanbied. Maar die Evangelie van Johannes gee self ' $n$ aanduiding van wat die intensie van die geskrif is, te wete Johannes 20: 30-31:

Jesus het nog baie ander wondertekens, wat nie in hierdie boek beskrywe is nie, voor sy dissipels gedoen. Maar hierdie wondertekens is beskrywe sodat julle kan glo dat Jesus die Christus is, die Seun van God, en sodat julle deur te glo, in sy Naam die lewe kan hê.

Met bogenoemde vertaling is gekies vir die aoristus konjunktief ten koste van die variante lesing wat 'n presens konjunktief voorstel. Die implikasie hiervan is dat die doel van die geskrif gesien word as ' $n$ poging om die lesers tot geloof te laat kom en nie om hulle die geloof te laat behou nie. Vir eersgenoemde lesing is daar genoeg eksterne getuienis, te wete die feit dat die lesing self wye steun uit al die teksfamilies geniet (Coetzee 1976a: 8). Ter ondersteuning van hierdie getuienis, kan die volgende interne getuienis aangevoer word (Coetzee):

- Die lesers is nie vertroud met die Joods-Palestynse aangeleenthede nie, met die gevolg dat die skrywer telkens moet verduidelik of vertaal. As die lesers reeds tot geloof gekom het, sou dit redelikerwys verwag kon word dat hulle basiese kennis van begrippe soos ' $\mathrm{Rabbi}$ ' en 'Messias' sou hê.

- Die skrywer lê ook nadruk op die gesprekke onder die toehoorders, naamlik of Jesus die Christus is of nie. Dit kan daarop dui dat die 
skrywer die leser se gevoelens vooruitloop en hom op díe wyse tot geloof wil bring.

Teenoor Hendriksen (1976: 34), Versteeg (1980: 103) en Schnackenburg (1980a: 42-43), wat almal vir die variante lesing kies en die doel van die evangelie as primêr geloofsversterkend sien, kan die doel na aanleiding van Coetzee (1976: 13) soos volg gestel word:

- geloofwekkend: die skrywer wil die leser bring tot ware geloof dat Jesus Christus die Messias en die Seun van God is en niemand anders nie;

- lewebrengend: deur die lesers tot geloof te bring, word hulle ook gebring tot die ewige lewe, wat in Jesus Christus alleen te vind is.

Met hierdie doel voor oë, wou die skrywer die lesers van sy geskrif tot 'n bepaalde standpuntinname dwing. Daarom praat Coetzee (1976: 13) van die Evangelie van Johannes as 'n tendensgeskrif: ' $n$ Geskrif wat sy lesers tot geloof in Jesus Christus wil laat tendeer. Hy gee geen bepaalde biografie van Jesus nie, maar sluit aan by die bestaande materiaal van die Sinoptiese Evangelies en voeg ander addisionele materiaal by om die heerlikheid van Jesus as die Messias aan te dui (Hendriksen 1976: 34). Hy voeg nie net feite by nie, maar lewer ook kommentaar op hierdie feite (Coetzee 1976: 13). Dit is juis hierdie kommentaar wat die Evangelie van Johannes so kenmerkend maak. Schmithals (in Bultmann 1971: 5) sê hierdie kommentaar verskaf 'n struktuur aan die Johannesevangelie, sodat dit nie bloot tradisies is wat aanmekaar geweef is nie, maar in die geheel 'n artistieke komposisie vorm.

Die vraag waarna gekyk moet word, is hoé hierdie kommentaar en tendensneiging van 'geloofwekkend' en 'lewebrengend' die weergawe van die historiese feite in die Vierde Evangelie beïnvloed. Hoe gebruik die skrywer die inligting tot sy beskikking in vergelyking met die Sinoptiese Evangelies, ten opsigte van die weergawes van die vermeerdering van die brode en die loop op die see, ten einde sy doel tot geloofsaanvaarding te bewerkstellig?

\subsection{Vergelyking met Sinoptiese Evangelies}

2.2.1 Johannes 6: 1-15 - Die vermeerdering van die brode Vergelyk tabel op bladsy 714 . 


\begin{tabular}{|c|c|c|c|c|}
\hline 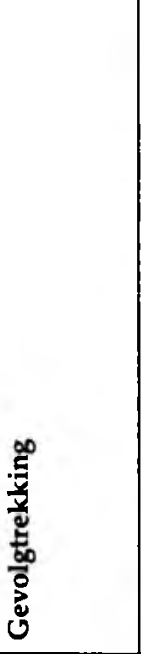 & 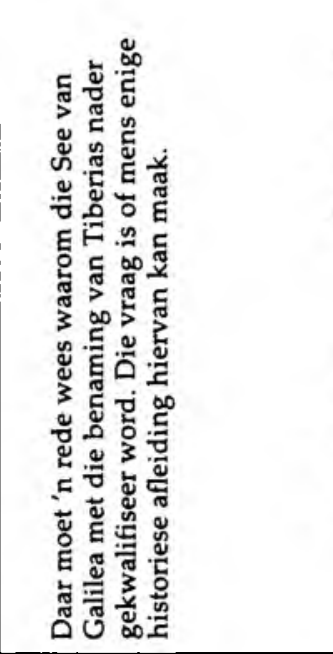 & 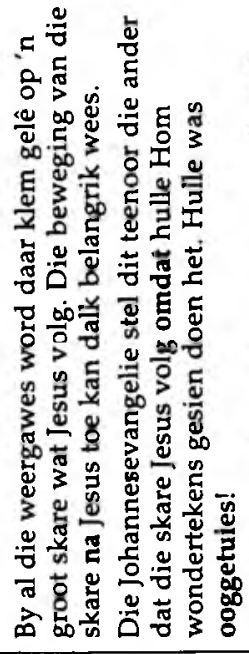 & 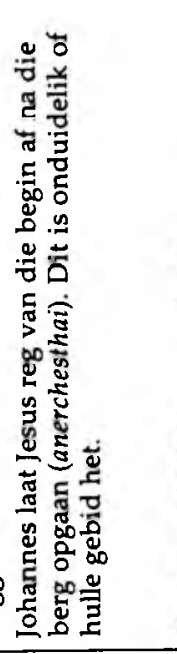 & 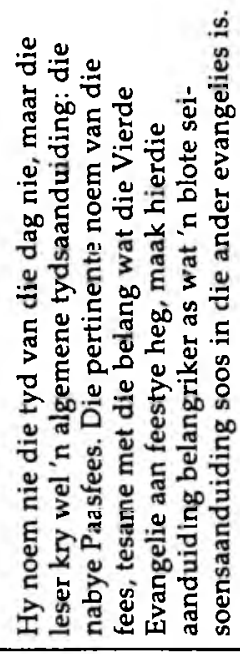 \\
\hline 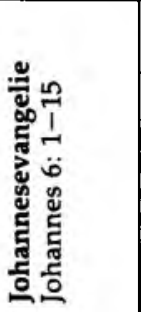 & 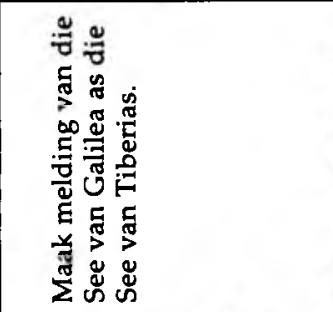 & 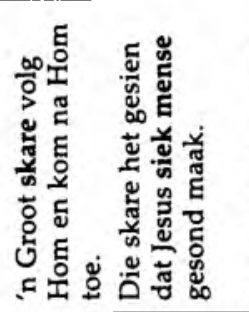 & 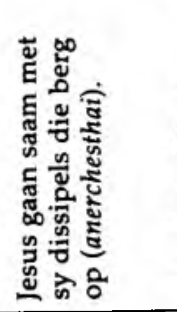 & 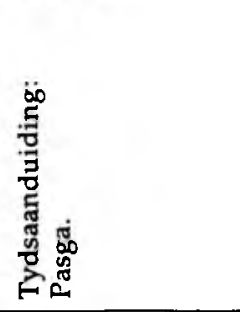 \\
\hline 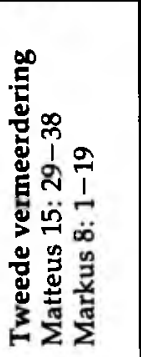 & 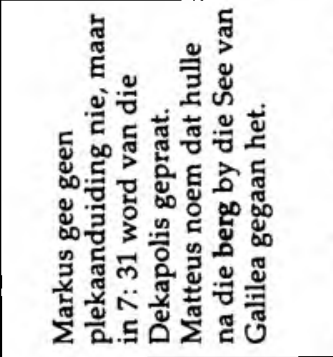 & 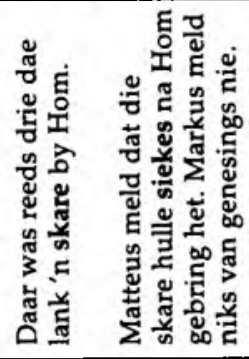 & 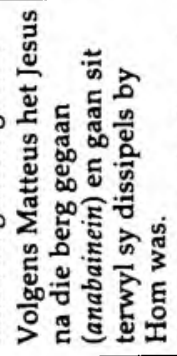 & 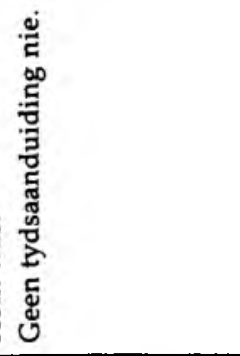 \\
\hline 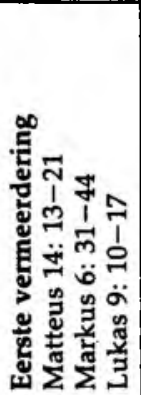 & 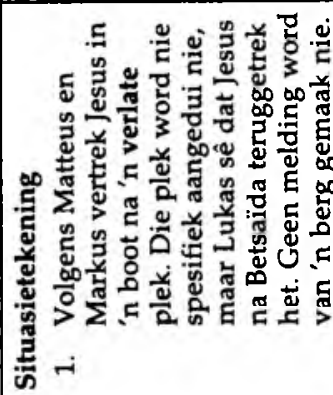 & 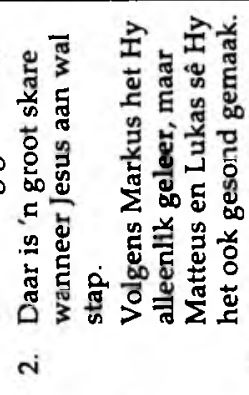 & 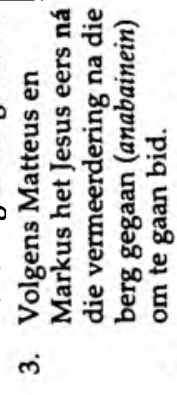 & 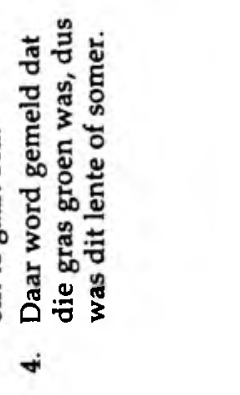 \\
\hline
\end{tabular}




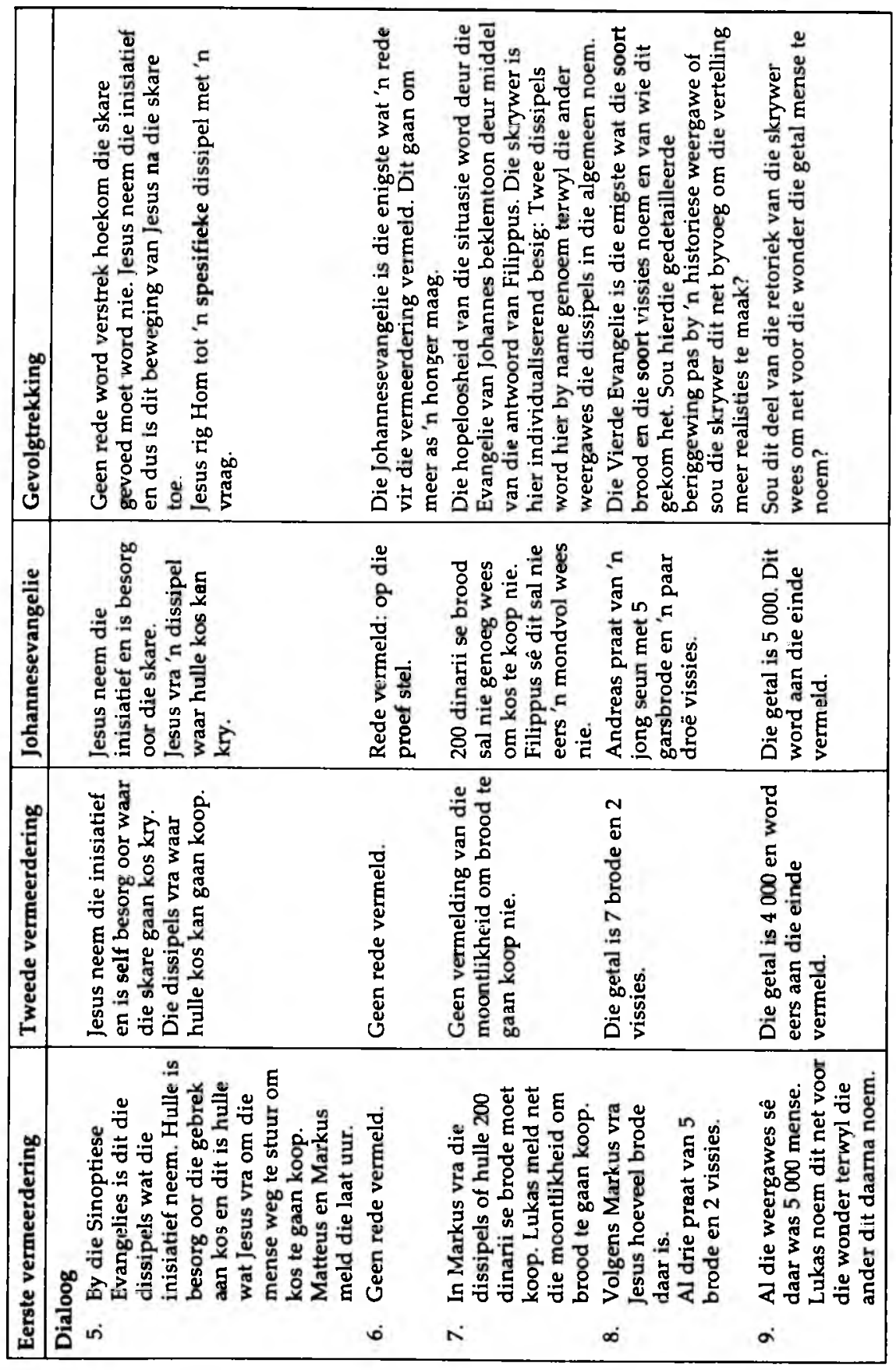




\begin{tabular}{|c|c|c|c|c|c|}
\hline 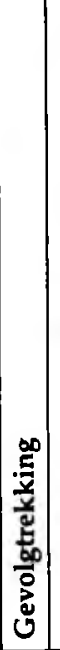 & 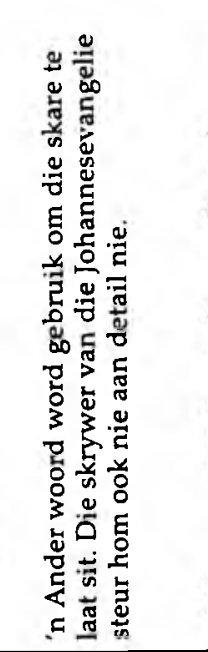 & 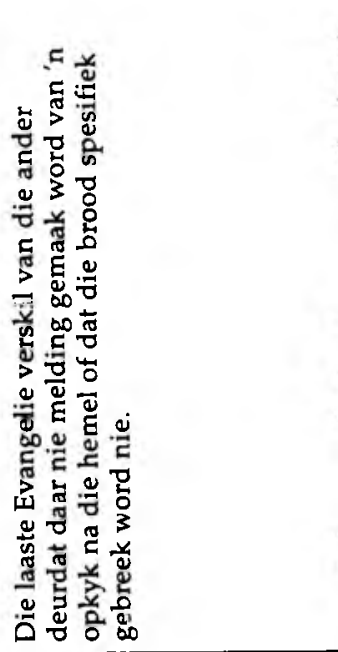 & 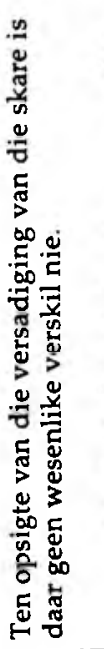 & 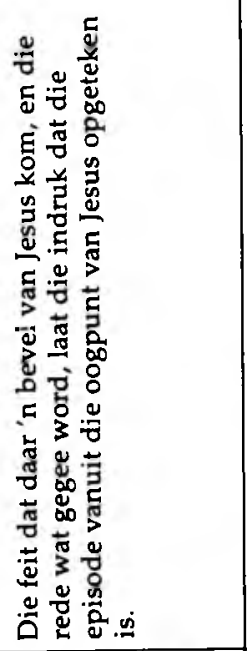 & 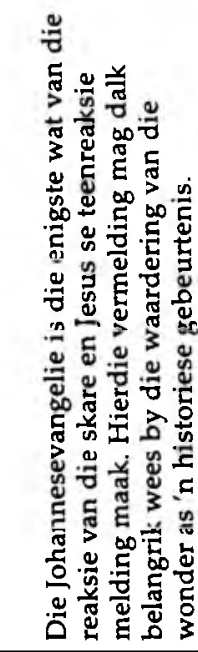 \\
\hline 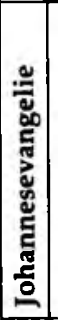 & 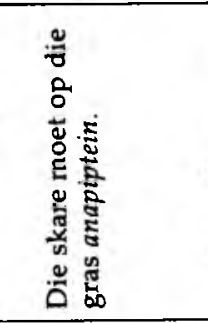 & 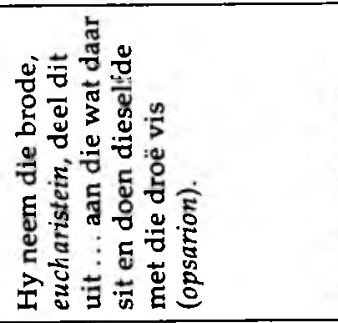 & 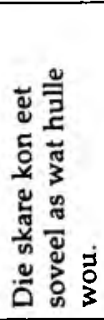 & 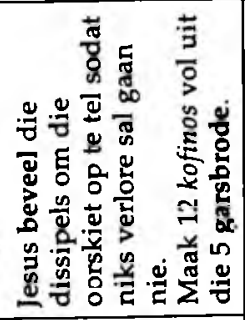 & 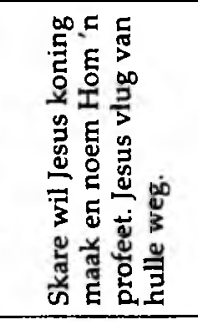 \\
\hline 邑 & 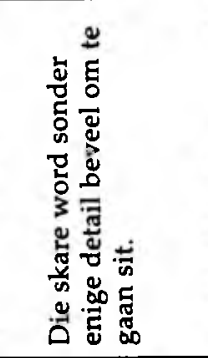 & 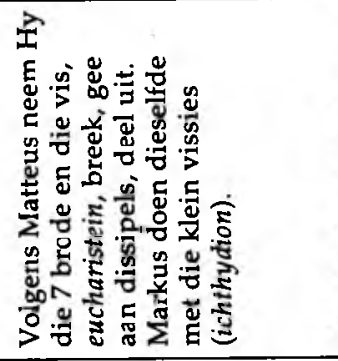 & 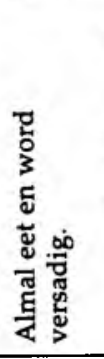 & 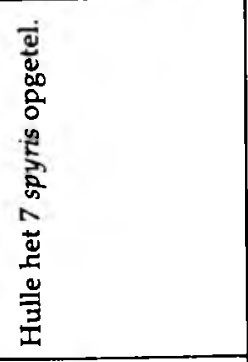 & $\begin{array}{l}\text { ญ் } \\
\text { ญ் }\end{array}$ \\
\hline 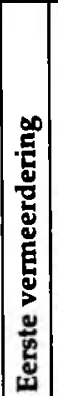 & 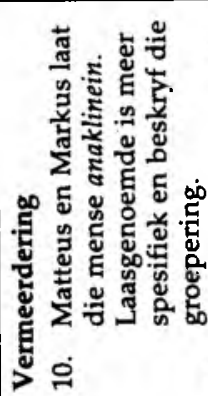 & 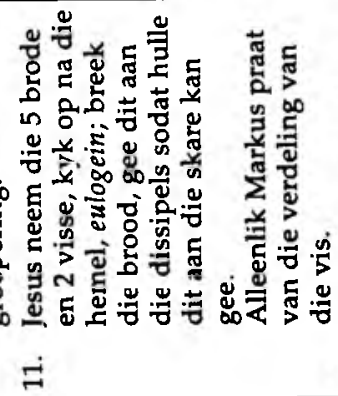 & 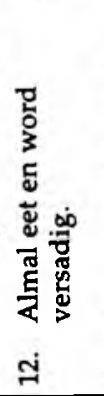 & 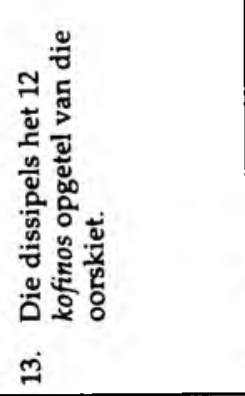 & 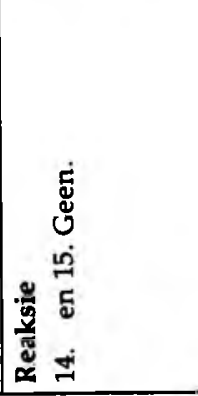 \\
\hline
\end{tabular}


2.2.2 Johannes 6: 15-21 - Die wandeling op die see

\begin{tabular}{|c|c|c|}
\hline & $\begin{array}{l}\text { Sinoptiese Evangelies } \\
\text { Matteus 14: } 22-34 \\
\text { Markus 6: } 45-56\end{array}$ & $\begin{array}{l}\text { Die Evangelie van Johannes } \\
\text { Johannes 6: } 16-21\end{array}$ \\
\hline 1. & $\begin{array}{l}\text { Situasietekening } \\
\text { Jesus laat sy dissipels in skuite } \\
\text { klim terwyl Hy onderneem om } \\
\text { die skare uitmekaar te laat gaan } \\
\text { terwyl Hy na die berg gaan om } \\
\text { te gaan bid. }\end{array}$ & $\begin{array}{l}\text { Jesus vlug van die skare af weg na } \\
\text { die berg. Die dissipels vertrek op eie } \\
\text { inisiatief. }\end{array}$ \\
\hline 2. & $\begin{array}{l}\text { Tydsaanduiding } \\
\text { Toe dit aand word was hulle } \\
\text { reeds op die see. Jesus kom na } \\
\text { hulle gedurende die vierde } \\
\text { nagwaak. }\end{array}$ & $\begin{array}{l}\text { Toe dit skemer word, het hulle na } \\
\text { die see gegaan. Jesus sou eers na } \\
\text { hulle kom as hulle 'n ent geroei het. }\end{array}$ \\
\hline 3. & $\begin{array}{l}\text { Weersomstandighede } \\
\text { Hulle het die wind van voor } \\
\text { gehad en die golwe het oor } \\
\text { hulle gespoel. Hulle kon nie juis } \\
\text { roei nie. }\end{array}$ & $\begin{array}{l}\text { Daar het 'n sterk wind gewaai en die } \\
\text { see het rof geword. Geen verdere } \\
\text { aanduiding van die weersgesteldheid } \\
\text { word gegee nie. }\end{array}$ \\
\hline 4. & $\begin{array}{l}\text { Afstand } \\
\text { Markus sê die dissipels was op } \\
\text { die see, maar dat Jesus hulle } \\
\text { kon sien. Matteus sê hulle was } \\
\text { baie stadia van die land af: in } \\
\text { die middel. }\end{array}$ & $\begin{array}{l}\text { Hulle het } 25 \text { tot } 30 \text { stadia ver geroei, } \\
\text { maar die afstand na die land word } \\
\text { nie aangedui nie. }\end{array}$ \\
\hline 5. & $\begin{array}{l}\text { Jesus loop op die see } \\
\text { Markus sê Jesus wou by die } \\
\text { dissipels verbyloop. }\end{array}$ & $\begin{array}{l}\text { Dit is onduidelik of die dissipels } \\
\text { Jesus op die see sien loop het en of } \\
\text { hulle nie naby die strand was en } \\
\text { Hom dáár sien loop het nie. }\end{array}$ \\
\hline 6. & $\begin{array}{l}\text { Reaksie } \\
\text { Die dissipels dink hulle sien 'n } \\
\text { spook. Hulle is baie bang. Jesus } \\
\text { verseker hulle egter dat daar } \\
\text { geen rede is om bang te wees } \\
\text { nie. }\end{array}$ & $\begin{array}{l}\text { Die dissipels is bang, maar word } \\
\text { deur Jesus gerusgestel. }\end{array}$ \\
\hline 7. & $\begin{array}{l}\text { Slot } \\
\text { Matteus vertel van Petrus wat } \\
\text { ook op die see probeer loop. } \\
\text { Markus vertel net dat Jesus in } \\
\text { die skuit geklim het, dat die } \\
\text { storm gevolglik bedaar het en } \\
\text { dat hulle by die land aangekom } \\
\text { het. }\end{array}$ & $\begin{array}{l}\text { Dit is onduidelik of Jesus in die } \\
\text { skuit geklim het. Die dissipels kom } \\
\text { egter dadelik op ' } n \text { wonderbaarlike } \\
\text { wyse by die land aan. }\end{array}$ \\
\hline
\end{tabular}


Die Johannese weergawe is baie korter en saakliker as die weergawe in die Sinoptiese Evangelies. Dit lyk of die skrywer dit eerder vanuit die gesigspunt van die dissipels wat vir Jesus gewag het vertel. Hierteenoor is die sinoptici se weergawe eerder vanuit die gesigspunt van Jesus gestruktureer, asof $\mathrm{Hy}$ kon sien hoe bang hulle was. Die Johannesevangelie sê niks van die dissipels se dilemma gedurende die storm nie. Die wonderelement is vanweë die stilmaak van die storm in die Sinoptiese Evangelies meer opvallend as in die Vierde Evangelie. Eersgenoemde hanteer dit soos 'n natuurwonder terwyl die leser van laasgenoemde moet aanvaar hy word 'n natuurwonder meegedeel. Die skrywer het alle klem op die ek is-uitspraak laat val en skep by die leser die indruk dat hy hier met 'n goddelike epifanie te doene het.

\subsection{Gevolgtrekking}

Hoe getrou aan die werklikheid die weergawe van die Johannesevangelie is, kan nie gesê word nie. Al wat die leser het, is die aanspraak van die skrywer self, naamlik dat sy getuienis waar is (Joh 21: 24) en dat dit geglo kan word. Dat daar onnoukeurighede is, is duidelik: Die presiese plek waar die wonder plaasgevind het, naamlik by Betsaïda of naby die stad Tiberias, die kwessie wie presies die inisiatief by die broodvermeerdering geneem het, Jesus (Johannesevangelie) of die dissipels (Sinoptiese Evangelies), die presiese afstand wat die dissipels op die see geroei het voordat Jesus na hulle aangeloop gekom het of voordat hulle Hom gesien het. Hoe staan hierdie onnoukeurighede in verband met die waarheidsaanspraak van die evangelie? Sou die skeiding van die vertellersperspektiefanalise tussen vertelde wêreld en werklike wêreld nie hier 'n oplossing bied nie, deur die onnoukeurighede te verklaar met die veronderstelling dat die skrywer, in die skeppingsproses van ' $n$ vertelde wêreld, dinge 'n bietjie verander het om sy verhaal beter te pas?

Aan die ander kant word hierdie wondertekens gerapporteer om 'n reaksie van geloof by die leser uit te lok. In hierdie sin kan die volgende byvoegings, naamlik die rede vir die vermeerdering (Joh 6: 6), die reaksie van die skare (Joh 6: 14-15) en die ek is-uitspraak (Joh 6: 20) bygevoeg wees om 'n reaksie by die leser te ontlok; as die skare en die dissipels op hierdie wyse gereageer het, wat is jou reaksie as leser? 'n Geweldige las word op die leser geplaas - hy moet reageer op 'n werklikheid van die dissipels en die skare. As hierdie werklikheid nie kan verwys na iets wat in die geskiedenis gebeur het en wat van belang 
is vir die leser nie, dan kan die leser alleen met simpatie en erbarming reageer. As die vertelde werklikheid, naamlik dat Jesus ook vir hóm die Messias en die Seun van God is, ook vir die leser ' $n$ beleefde werklikheid word, soos in Johannes 20: 30-31 gesuggereer, dan kan die vertelde wêreld nie van die werklike wêreld losgemaak word nie. Uit die oogmerk van die Evangelie van Johannes wil dit voorkom of die leser met geloof moet reageer op iets wat werklik in die geskiedenis plaasgevind het. Die vraag wat nou beantwoord moet word, is wat die verband tussen die vertelde en werklike wêreld is. Kan historisiteit 'n waarborg vir die waarheid wees?

\section{VERTELLERSPERSPEKTIEFANALISE VAN JOHANNES 6: 1-21}

\subsection{Die verteller}

\subsubsection{Ideologiese perspektief}

Die basis van die vertellersperspektiefanalise is dat daar ' $n$ verteller is wat deur die skrywer as 'n retoriese instrument gebruik word om die verhaal te vertel en te laat vlot (Rhoads 1982: 35). Hierdie verteller vertel die verhaal vanuit ' $n$ bepaalde hoek of perspektief (Van Aarde 1982: 60):

- tegniese perspektief: Dit is die hoek waaruit die verteller die vertelde wêreld waarneem en dit vir die leser aanbied;

- ideologiese perspektief: Dit is die hoek waaruit die verteller die vertelde wêreld evalueer en dit waarneem soos hy dit waarneem.

Dit kan gebeur dat die perspektief van die skrywer met dié van die verteller en die hoofkarakter saamval (Van Aarde 1982: 63). Dit word dan 'n simplekse vertelling genoem.

Iets soortgelyks word in die Johannesevangelie gevind. Johannes 6: 1-21 is in die derde persoon geskrywe en dui nêrens aan dat die skrywer of verteller 'n aktiewe karakter van die verhaal is nie. Aan die einde van die boek word berig dat die dissipel wat hierdie dinge berig, se getuienis waar is. Die leser weet die verteller is ten minste ' $n$ dissipel van Jesus en by wyse van eliminasie kan gesê word dat hy, Johannes, die lieflingdissipel is (Coetzee sj a: 2-3).

Omdat die verteller een van die dissipels is, is hy eintlik ook een van die karakters van die verhaal. Die feit dat hy deel is van die verhaal, verhoog die waarde van die gesigshoek waaruit hy die gebeure vertel, naamlik'n alomteenwoordige perspektief. Hy besit onbeperkte kennis 
in vergelyking met die beperking van die ander karakters. In Johannes 6: 6 word die rede vermeld waarom Jesus bepaalde vrae aan sekere dissipels gestel het: Hy wou hulle op die proef stel. Die karakters weet dit nie, maar die verteller deel dit aan die leser mee. Die vraag is net: Hoe het die verteller dit geweet?

Rhoads (1982: 38) sê om in die verstand van iemand te kan lees, gee aan die verteller 'n gesagsposisie by die leser. Laasgenoemde vertrou hom as ' $n$ betroubare gids in die wêreld van die verhaal. As verteller wil die lieflingdissipel juis by die leser vertroue inboesem en sê hy twee maal dat sy getuienis waar is (Joh 19: 35; 21: 24). Dit gaan egter nie daarom of die verteller in die verstand van Jesus kon inlees nie. As deel van die binnekring van die dissipels was dit moontlik dat $\mathrm{Hy}$ dit aan hulle kon meedeel. Die skrywer of verteller was immers ' $n$ ooggetuie en het alles waargeneem. Binne die vertelling van Johannes 6: 1-21 is die getuienis geloofwaardig. Die verteller vertel die gebeure nie vanuit sy eie perspektief nie, maar vanuit díe van sy karakters. Die byvoeging van vers 6 is ' $n$ aanduiding dat hy die episode vanuit die perspektief van Jesus vertel. Hierteenoor blyk dat hy die episode van die wandel op die see vanuit die perspektief van die dissipels vertel: Hy vertel breedvoerig wat die dissipels gedoen het, maar nie wat Jesus gedoen het terwyl die dissipels op Hom gewag het nie. Tog word die alomteenwoordige perspektief van die verteller beperk, omdat hy ooggetuie is, kan hy nie dinge vertel waar hy nie teenwoordig is nie.

\subsubsection{Vertelpatrone}

Die verteller gebruik bepaalde vertelpatrone om die boodskap doeltreffend oor te dra. Hy gebruik in die eerste plek 'n herhaalpatroon. In Johannes 6: 1-15 word woorde soos berg (vv 3, 15), brood (vv 5, 7, 9, 11) en brokstukke (vv 12,13) herhaal. Dit hou die leser op sy tone vir belangrike temas in een episode. Die herhaling van brood en brokstukke laat die klem op die wonder self val, terwyl die herhaling van berg die klem laat val op die omstandighede waarbinne die wonder plaasvind. Die herhaling van brood later in die aanspraak in Johannes 6: 21 en die daaropvolgende verse, veroorsaak dat die leser die wonder van die vermeerdering van die brode hieraan koppel (Rhoads 1982: 46).

Die verteller maak ook gebruik van die sogenaamde tweestappeprogressie in sy verhaal. Hierdie patroon vorm wanneer een ding op twee verskillende maniere, direk na mekaar gesê word, byvoorbeeld:

Johannes 6: 1 - die see van Galilea, dit wil sê die See van Tiberias; 6: 8 - Andreas, die broer van Simon Petrus; 


\section{6: $14-15-\mathrm{Hy}$ is waarlik die profeet}

... om Hom koning te maak.

Hierdie stylfiguur is nie blote herhaling nie, maar die tweede gedeelte maak die eerste gedeelte duideliker en plaas die klem op die tweede deel (Rhoads 1982: 47).

Die nadere lokalisering van die See van Galilea kan historiese probleme skep. Sommige geleerdes wil uit Johannes 6: 23 konkludeer dat die plek waar die wonder plaasgevind het, naby die stad Tiberias was, wat aan die westekant van die See van Galilea gelê het. Lukas noem die plek weer Betsaïda, wat aan die oostekant geleë was. Op grond van die gebruik van die tweestappe-progressie moes die verteller rede gehad het om die See Tiberias te noem. Die Griekse teks plaas die woord Tiberias in die genitief en dit behoort aposisioneel verklaar te word: die See van Galilea, naamlik van Tiberias. Die stad Tiberias is eers in die jaar twintig na Christus gebou. Die see was eers in die tyd van die skryf van die Johannesevangelie bekend as die See van Tiberias (Morris 1971: 341). Hendriksen (1976: 217) sê die lesers van Klein-Asië was beter bekend met die naam Tiberias. Daarom gebruik hy die naam Tiberias. Om hieruit te konkludeer dat die vermeerdering van die brode by of naby die stad Tiberias plaasgevind het, moet die genitief as 'n genitief van plek beskou word. Maar so' $n$ genitief is baie raar in die Nuwe Testament en dit skep ongetwyfeld historiese probleme.

\subsubsection{Instrumente}

Die verteller gebruik nog twee maniere om die leser by die verhaal te betrek en die spanning te verhoog, naamlik vrae en ironie.

Vrae skep 'n bepaalde verwagting by die leser. Die twee vrae in verse 5 en 9 word nie direk deur òf die dissipels ò Jesus beantwoord nie. Dit word beantwoord deur die teken van die vermeerdering van die brood. Die wyse waarop die dissipels Jesus antwoord, dui op hulle gebrek aan geloof in wat Jesus kán doen (Rhoads 1982: 50). Dit verhoog die konflik tussen Jesus en sy dissipels. Maar die leser vra homself dieselfde vraag af as die dissipels en identifiseer hom met hulle kleingeloof. Dat hierdie vraestellery 'n stylmiddel is, is duidelik vanweë die feit dat die weergawes in die evangelies nie ooreenstem nie. By die sinoptici is dit die dissipels wat die vrae stel oor die verskaffing van voedsel, maar by die Vierde Evangelie is dit Jesus wat die inisiatief neem. Die besorgdheid oor die voedselverskaffing word deur die evangelieskrywers verskillend uitgedruk. 
Met betrekking tot ironie onderskei Rhoads (1982: 60) tussen verbale en situasionele ironie. By laasgenoemde is daar 'n verskil tussen dit wat die karakter verwag en dit wat in werklikheid gebeur. Situasionele ironie word in verse 14-15 gevind. Die skare is vas oortuig dat dit wat hulle sê, naamlik dat Jesus die profeet is, die waarheid is. Daarom wil hulle Hom koning maak. Die ironie is egter dat Hy méér as die profeet is wat hulle verwag en dat sy koninkryk nie 'n aardse koninkryk is nie (Schnackenburg 1980b: 20). Verbale ironie word gevind waar iemand een ding sê en 'n ander ding bedoel. Dit lyk nie of daar in hierdie gedeelte verbale ironie is nie.

Die vraag waarmee Schnackenburg (1980b: 18) hom besig hou, is of die skrywer, vanweë die feit dat hy in verse 14-15 iets berig wat nie in die weergawes van die ander drie Evangelies voorkom nie, die leser hier ' $n$ historiese weergawe gee. Volgens sy redenasie is dit moeilik om te verstaan waarom die sinoptici daaroor sal swyg. Selfs by die gesprek oor die brood van die lewe verwys Jesus nie na die feit dat hulle Hom wou koning maak nie, maar net na die brood wat hulle geëet het. Die implikasie is: Omdat die Sinoptiese Evangelies daaroor swyg, staan dít wat die Evangelie van Johannes die leser in hierdie opsig meedeel, nie histories vas nie. Schnackenburg wil nie die vraag histories beantwoord nie, maar vra na die narratiewe intensie. Morris (1971: 346-347), daarenteen, kom tot die volgende gevolgtrekking:

This is another indication that the Gospel is early, or at least it is faithful to the facts. At the end of the first century, when Christianity was coming into conflict with the State, there would be no temptation to invent and little inclination to record that one result of Jesus' 'signs' was that people wished to make a king out of him.

Volgens die vertellersperspektiefanalise is dit irrelevant of hierdie gedeelte op vaste historiese grond staan. Dit gaan nie vir die leser om 'n terugkoppeling na 'n werklike wêreld nie, maar om wat die effek vir die leser is van die vermelding van die reaksie van die skare. Die skrywer of verteller gebruik hierdie instrument van ironie om van die leser 'n bepaalde reaksie af te dwing.

Die verteller gebruik die instrument van ironie ook op 'n ander wyse. Deur die toevoeging van vers 6 word 'n dramatiese ironie geskep; die leser kom iets te wete wat die ander karakters nie weet nie. Deurdat hy betrek word by 'n geheim waarvan die ander karakters onkundig ingetrek word, kan die leser verstaan waarom die karakters so 'blind' 
optree. Hy het simpatie met hulle. Andersyds word 'n afstand geskep omdat hy wonder hoe die karakters in die omstandighede gaan optree. Deur die dramatiese ironie sien die leser wat die werklike toedrag van sake is en verstaan hy die situasionele ironie aan die einde. Hierdie ironie word uiteindelik op homself uitgekeer: Hy moet homself afvra waar hy staan ten opsigte van die twee wonders van Jesus: Glo hy dat Hy die Messias is of nie?

\subsection{Dekor: tyd en ruimte}

Die dekor van 'n verhaal verleen 'n konteks aan die konflikte en aan die handelinge van die karakters (Rhoads 1982: 63). Dekor het baie funksies: Dit bepaal atmosfeer, konflik, bring karaktertrekke na vore, gee kommentaar en roep assosiasies op. Die dekor in hierdie gedeelte is die berg en die see en die tydsaanduiding is die nabye Pasga.

Die konteks van die see kom net in Johannes 6 voor en dan eers weer in Johannes 21 . As mens kyk na die gesprek van Jesus ná die tekens van die vermeerdering van die brode en die wandel op die see, dan blyk dit dat Ou-Testamentiese motiewe ' $n$ rol speel. Die hele uittog en die Pasga word in herinnering geroep met die verwysing na manna en die rol van Moses. Die deurtog deur die Skelfsee word egter nie eksplisiet in herinnering geroep nie. Dit is daarom moeilik om die wandel op die see daarmee in verband te bring (Schnackenburg, 1980b: 30).

Die verwysing na die berg in die Johannesevangelie speel nie so 'n belangrike rol as in die Sinoptiese Evangelies nie. Die verwysing na ' $n$ berg word alleenlik in Johannes 4: 20, 21; 6: 3, 15 en 8: 1 gevind. Die berg in Johannes 4 is die berg Geresim waar die Samaritane aanbid. Morris (1971: 342) sien geen diepere betekenis in die verwysing na die berg nie. Volgens die vertellersperspektiefanalise het ruimte egter 'n bepaalde funksie: Dis 'n speelruimte of 'n belangeruimte (Van Aarde 1982: 78). Belangeruimte is nie blote lokaliteitsaanduiding nie, maar trek 'n verband tussen die ruimte, die gebeure en die karakters. Nóg Calvyn, nóg Morris, nóg Dodd sien enige belangeruimte in die berg. Dit is vir hulle alleen maar 'n speelruimte waar Jesus ò sy dissipels leer ò alleen gaan om te bid (Dodd, 1980: 333).

Schnackenburg (1980b: 14) ken aan die berg die posisie van 'n bepaalde belangeruimte toe as hy sê die gaan na die berg dui op die gesag van Jesus en die beeld van Moses op die berg Sinaï word daardeur in herinnering geroep. Binne hierdie opset toon Jesus dat $\mathrm{Hy}$ iemand meer is as Moses. Hierdie funksie van die berg word in vers 15 
bevestig: Die feit dat Jesus alleen berg toe gaan, dui op 'n 'lonely closeness to God' (Schnackenburg 1980b: 20). Moses het ook so alleen na die berg gegaan (Eks 24: 15). Die berg is dus reliëfgewend tot die gebeure van die wonder: 'The mountain is also a setting for revelation... The mountain setting triggers these associations (met die OT GF S), thereby enriching the meanings of the episode which occur there' (Rhoads 1982: 67).

Dat dit hier om meer as Ou-Testamentiese motiewe gaan, blyk uit die tydsverwysing in vers 4: 'En die Pasga, die fees van die Jode was naby'. Tydsaanduiding speel in die Johannesevangelie ' $n$ belangrike rol. Telkens is daar ' $n$ aansluiting by een of ander feesdag, ' $n$ wonder en ' $n$ aanspraak wat daarop volg, wat pas by die wese van die feesdag (Coetzee, sj a: 15). Die vermelding van die Pasga is heel gepas, want dit skep ' $n$ bepaalde atmosfeer. Brood word vermeerder en met die Paasfees word ongesuurde brood geëet wat herinner aan die veertig jaar in die woestyn. Jesus koppel sy uitspraak dat Hý die brood van die lewe is juis hieraan. Brown (1966: 245) maak ook melding van die feit dat in hierdie tyd, daar in sinagoges dele uit die Ou Testament met betrekking tot die uittog en die manna uit die hemel gelees is. Hierdie gebeure en assosiasies sou dan nog vars in die geheue van die skare en die dissipels wees, wanneer Jesus die brood vermeerder en op die see loop.

Vir Dodd (1980: 333) is hierdie gebeure bowenal simbolies:

Here we are justified in seeking for something more than the surface meaning. Dramatically, the season is appropriate enough, and there is no reason why as a matter of historical fact the incidents ... may not have happened about Passover time.

Die diepere betekenis en simbool wat hy soek (saam met Barret 1982: 66 vv) is 'n verwysing na die Christelike Nagmaal.

Waar die leser by die Evangelie van Johannes te doen het met 'n bepaalde stofseleksie, en met bepaalde perspektiewe en tendense, perspektiewe en tendensgeskrif, moet daar waarde geheg word aan die tydsaanduiding. Die vraag is of dit enige historiese waarde het. Die tydsverwysing staan in verband met ' $n$ bepaalde kronologiese verloop. Die Vierde Evangelie se kronologie verskil van die Sinoptiese Evangelies. Dit veroorsaak dat die tydsverloop nie letterlik opgeneem kan word nie. Die meeste wat op die oomblik van die gebruik van die feesdae en kronologie in die Johannesevangelie gesê kan word, is dat 
dit gebruik word op ' $n$ wyse wat bedoel is om die leser in 'n sekere rigting te laat neig en sekere dinge by hom tuis te bring.

Die gebruik van die berg en die see as dekor gee aan die twee episodes ' $n$ bepaalde beweging. In Johannes 6: 1 gaan Jesus na die oorkant van die See van Galilea, in Johannes 6: 15 gaan Hy alleen na die berg, in Johannes 6: 21 kom hulle op ' $n$ wonderbaarlike wyse by die land aan. Daar is ook ' $n$ voortdurende beweging van die skare op pad na Jesus.

Beweging vind plaas tussen Jesus na sy dissipels en van die skare na Jesus toe. Dit is opmerklik dat die dissipels nooit na Jesus kom nie, maar dat dit altyd Jesus is wat na hulle gaan. Dit is nogal betekenisvol dat sodra Jesus by hulle in die boot kom, die dissipels dadelik by die land aankom. Hierteenoor is dit altyd die skare wat na Jesus op pad is. Nêrens word uitdruklik vermeld dat $\mathrm{Hy}$ na die skare kom nie. Uit Vorster en Steyn (1979: 40) se bespreking van Markus 5, lyk dit asof dit toelaatbaar is om simboliese betekenis aan beweging te heg. Dit sou dus geregverdig wees om binne die grense van die vertellersperspektiefanalise die beweging as simbolies te beskou. Die vraag is net watter simboliek hierin gelees kan en mag word. Die verleiding na subjektiwisme is sterk.

Hierdie bewegingspatroon van Jesus veroorsaak egter kronologiese probleme. Bultmann (1971: 209) verplaas die episode van die broodvermeerdering na hoofstuk vier en laat hoofstukke vyf en sewe hoofstuk ses opvolg. As Jesus volgens Johannes 6: 1 na die oorkant van die See van Galilea moes gaan, moes Hy aan die ander kant gewees het. Maar die gebeure vooraf is die genesing op die sabbat by die bad van Betesda in Jerusalem. Die gebeure in hoofstuk sewe vind ook in Jerusalem plaas. Die gebeure in hoofstukke vyf en sewe pas bymekaar terwyl die gebeure in vier en ses bymekaar pas. Schnackenburg (1980b: 6) sê die omruiling van die hoofstukke sal die verstaan van die verwysing na die feesdag makliker maak. Nadat Jesus na Galilea teruggegaan het (Joh 4: 45 ), het Hy Jerusalem 'n ruk lank vermy. Die fees waarvan daar sprake is in Johannes 5: 1, sou dan die Pinksterfees wees (wat ná die Paasfees in Johannes 5: 4 plaasvind). Hierdie volgorde stem ook ooreen met die kronologie van die ander Evangelies.

Hoeveel waarde moet egter aan die beweging geheg word as dit in reëele terme moeilik verklaarbaar is? Van Aarde (1982: 77) is van mening dat geografiese verwysing nie lewensvreemd moet wees nie. Dieselfde kan sekerlik van begewing gesê word, aangesien dit tog beweging tussen geografiese punte is. Die wyse waarop met beweging 
in die Evangelie van Johannes gewerk word, skyn lewensvreemd te wees: Jesus word letterlik deur die skrywer of verteller tussen Galilea en Judea rondgejaag. Rhoads (1982: 68) sê die volgende oor beweging:

Frequent movement suggest a hurried journey underscoring the urgency of Jesus' message. It also enhances Jesus' authority, reestablished in city after city. Travel also emphasizes the extent to which God's rule is proclaimed throughout the nation and beyond.

Dit lyk asof Jesus voortdurend aan die beweeg is vanweë probleme of teenstand (Joh 6: 15; 7: 1). Dit is opmerklik dat die verteller of skrywer bloedweinig van Jesus se dienswerk in Galilea weergee: Slegs Johannes $2: 1-11 ; 4: 43-54 ; 6 ; 10: 40-42$. Maar tot en met hoofstuk ses word die tekens van Jesus telkens met tekens in Galilea en Judea gekontrasteer. Op grond van die kontras moet die beweging nie histories beoordeel word nie.

\subsection{Plot}

Oor plot sê Aristoteles die volgende (1450b):

holon de estin to echon archèn kai meson kai teleutēn.

Die plot bestaan uit gebeure wat kronologies en kousaal met mekaar in verband staan (Van Aarde 1982: 73). Die begin volg nie iets op op grond van noodsaak of reël nie, maar natuurlik. Die einde is wel die gevolg van noodsaak of reël terwyl die middel die begin noodwendig opvolg (Aristoteles 1450b).

Binne die geheelstruktuur van die Evangelie is daar gebeure wat die agtergrond vir hoofstuk ses vorm terwyl ander gebeure die onmiddelike handelinge van die hoofstuk is. In hoofstuk vyf word die agtergrond of voorlope van die gebeure gevind: Na die genesing van die siek man van Betesda wil die Jode Jesus se lewe neem. Maar Hy sê Hy maak lewend wie $\mathrm{Hy}$ wil. In Hom het die bedeling van die lewe reeds gekom. In hoofstuk ses illustreer $\mathrm{Hy}$ met die vermeerdering van die brood en die loop op die see, hoe hierdie bedeling reeds aangebreek het: $\mathrm{Hy}$ is die brood van die lewe, wie na Hom toe kom, sal nooit weer honger kry nie. Die begin van hoofstuk ses is kronologies moeilik in verband te bring met die vorige hoofstuk, maar dit kom voor of hierdie gebeure hoofstuk vyf op 'n natuurlike wyse opvolg. 
Van Aarde (1982: 75) praat van 'n handelingslyn met 'n suksesvolle afloop van die protagonis se sending na'n objek. Hierby mag 'n tweede handelingslyn gevoeg word wat 'n newesekwensie vorm. Die versoeking is groot om vanweë die struktuur - twee tekens gevolg deur 'n aanspraak (Coetzee 1976: 18) - die seewandeling as 'n newesekwensie van die eerste teken naamlik die vermeerdering van die brode te beskou. Vroeër is melding gemaak van die sogenaamde tweestapprogressie. Die hele struktuur van Johannes 6: 1-21 vertoon elemente hiervan. Hoofstuk ses in sy geheel, vertoon ook elemente hiervan: Tekens word gegee en dan volg daar 'n verklaring om die diepere betekenis aan te toon. Tussen die twee tekens is dit ook die geval. Die tweede is ' $n$ nadere verklaring van die eerste. In die vermeerdering van die brode sien die Jode Jesus as ' $n$ aardse verlosser en wil hulle Hom daarom koning maak. Hulle beweeg letterlik en figuurlik na Jesus toe. Hy wys egter hulle aanbod van die hand en begin om Hom en sy dissipels af te sonder. Die skare het die Godsopenbaring verkeerd verstaan. Die vraag is hoe die dissipels dit verstaan het. Het hulle die toets waarvan in vers 6 melding gemaak word, geslaag? In die tweede teken van die seewandeling openbaar Jesus Hom in die besonder aan die dissipels as God, die ek is, soos Hy Hom ook in die Ou Testament met krag en majesteit geopenbaar het (Dodd 1980: 345; Schnackenburg 1980b: 27). Hy is iemand wat nie deur tradisionele titels soos profeet en koning omvat kan word nie.

As bogenoemde die geval is, moet die volgende aanvaar word (Van Aarde 1982: 75):

- die vertelling is volgens dieperliggende prinsipes as blote kousale of kronologiese prinsipes georganiseer;

- dit lê op die vlak van die verteller se ideologiese perspektief, met name op die topografiese en tydsvlakke.

Die doel van die wandeling op die see is nie soos Fuller (1971: 102) beweer, net om Jesus by die skare uit te bring, nadat hulle van mekaar verwyder is nie. Die verteller borduur weliswaar nie voort op die betekenis van die wandeling op die see nie, maar dit beteken nie dit is bloot ' $n$ instrument van die skrywer om beweging te laat vlot nie. Dieselfde karakters is aanwesig: Jesus en die dissipels, uitgesonderd die skare. Sou hier ' $n$ besondere toespitsing kom van die skare in die wye openbare situasie na meer private omstandighede tussen Jesus en sy dissipels? Sou dit ook ' $n$ nadere toespitsing kon beteken van wat $\mathrm{Hy}$ 
aan die skare wou toon? 'n Strukturele vergelyking wys dat dit wel die geval is.

\section{BEGINSTUK}

Johannes 6: $1-4$ is 'n situasietekening waarbinne die verhaal van die wonder hom afspeel: Let op die plekaanduiding van die berg wat Jesus bestyg en die tydsaanduiding van die nabye Pasga.

Johannes 6: 16 is ook 'n situasietekening waarbinne die wonder hom afspeel: Let op die tydsaanduiding van die naderende nag en die plek waarheen die dissipels gaan, naamlik die see.

\section{MIDDELSTUK}

Aan die hand van Van der Loos (1968: 120) kan die volgende elemente onderskei word:

Johannes 6: 5-13 - vermeerdering van die brood

1. Die aard van die probleem wat aanleiding gee tot die wonder:

- vers 5 - waar gaan die mense kos kry?;

- vers 6 - die rede waarom hier 'n probleem is: Jesus wil sy dissipels op die proef stel.

2. Die mislukking van die mens:

- vers 7 - vanweë 'n gebrek aan geld is die dissipels nie in staat om aan die mense voedsel te verskaf nie.

3. Die moeilikheidsgraad van die wonder:

- vers 8-10 - daar is net vyf brode en twee visse vir vyfduisend mense! Hoe kry mens dit verdeel?

4. Behandeling van die probleem:

- vers 11 - die probleem word opgelos deur die wonderbaarlike vermeerdering van die visse en die brode.

5. Bewyse van die realiteit van die wonder:

- verse 12-13 - daar word twaalf mandjies vol brokstukke opgetel. 
Johannes 6: 17-20 - die wandeling op die see

1. Probleemstelling:

- vers 17 - die dissipels wil in die donker sonder Jesus oor die see vaar.

2. Moeilikheidsgraad van die wonder:

- vers 18 - die oortog sal moeilik wees want die see is ontstuimig.

3. Behandeling van die probleem:

- vers 19a - Jesus kom self uit die niet op die see na hulle aangeloop.

4. Reaksie van die omstanders:

- vers $19 b$ - die dissipels word bang.

5. Teenreaksie van Jesus:

- vers 20 - Hy stel die dissipels gerus en openbaar Homself as God.

6. Reaksie van die dissipels:

- vers $21 \mathrm{a}$ - hulle is gewillig om Jesus in die skuit te neem.

\section{SLOTSTUK}

Johannes 6: 14-15 vorm die einde van die episode van die vermeerdering van die brood. Hierin is die reaksie van die omstanders opgeteken: Hulle was so beindruk met dit wat gebeur het, dat hulle tot ' $n$ konkrete belydenis oor Jesus kom, maar in hulle ywer pas hulle dit verkeerd toe wanneer hulle Hom wil koning maak.

Die slot van die tweede episode, die seewandeling, word in vers $21 \mathrm{~b}$ gevind waar die bewys van die realiteit van die wonder opgeteken is: Hulle het dadelik aangekom by die plek waar hulle wil wees.

Die twee wonders verskil in die middelstuk struktureel van mekaar. Waar die eerste swyg oor die reaksie van die dissipels, daar word in die tweede ' $n$ beskrywing daarvan gegee. Waar Jesus Hom in die eerste wonder nie deur middel van die woord geopenbaar het nie, daar gebeur dit wel in die tweede. In die tweede word daar iets meer oor die heerlikheid van Jesus gesê. Die konflik wat in vers 6 tussen die dissipels en Jesus gesuggereer word, word in die tweede wonder tot ' $n$ hoogtepunt gevoer: Hy wil eintlik van die dissipels weet wie hulle dink $\mathrm{Hy}$ in werklikheid is. 
Die konflik kom van twee kante af. Aan die een kant is daar die dissipels (in die wyer en enger kring) wat die tekens van Jesus moet verstaan, sonder dat hulle daarop voorberei word of 'n rigtingaanduiding kry (Rhoads 1982: 90). Uit vers 6 is dit duidelik dat van die dissipels getoets moet word en dat hulle nie daarop voorbereid is nie. Hulle gevolglike ongeloof spreek ook uit die vrae wat hulle vra. Hulle is heeltemal onseker waar om kos te kry vir so baie mense. Hulle is ook in die duisternis wat die teken van Jesus beteken. Eers nadat Hy die teken aan hulle verduidelik het en op Hom van toepassing gemaak het, kom die dissipels onder leiding van Petrus tot 'n belydenis dat $\mathrm{Hy}$ die Christus, die Seun van God is (Joh 6: 69). Die ander dissipels (in die wyer kring) verstaan nie die teken en die verklaring daarvan nie. Hulle is te veel op aardse dinge ingestel, soos 'n aardse messias en honger mae. Daarom is die woord vir hulle hard (Joh 6: 60).

Aan die ander kant moes Jesus baie gefrustreerd gewees het met die mense wat $\mathrm{Hy}$ uitgekies het as sy dissipels, maar wat nie kon begryp nie. By die eerste wonder is die sigbare teken die brood en het iets van die wese van Jesus tot die mense deurgeskemer: Hulle sien Hom as 'n profeet. Maar as teken openbaar die wonder die aard van Hom wat aan die werk is. Rengstorf (1971: 245) sê dit gaan om die kwaliteit van die teken en nie die kwantiteit nie en dat hierdie tekens kenmerke dra van die Messiaanse tyd en Messiaanse epifanie-wonders is. Die vermeerdering van die brood wys na die verwagting dat die Messiaanse tyd 'n einde sal maak aan aardse honger en dors.

Die skare het hierdie teken verkeerdelik opgeneem as een van kwantiteit en nie van kwaliteit nie. Deur die veelheid van die brood is hulle honger mae gevul en is Jesus vir hulle ' $n$ kragtige aardse bevryder. Die kwaliteit van die teken sien hulle nie raak nie: Hulle kyk verby die openbaring van sy heerlikheid. Jesus ag dit nodig om hierdie saak onder sy dissipels in die reine te bring met nog ' $n$ teken, ' $n$ bewys waarmee Hy Homself kan bevestig. Hy doen dit deur op die see te loop en Hom aan die dissipels met dieselfde woorde te openbaar as wat God dit aan Israel in die woestyn by Sinaï gedoen het. Hiermee word dieselfde assosiasies van gesag èn belofte soos in die Ou Testament (Jes 43: $1-3$; 11) in herinnering geroep. Dit dien as inleiding tot die aanspraak wat hierna volg (Schnackenburg 1980b: 87).

Die konflik in hierdie twee episodes word opgelos as die dissipels Jesus in die skuit wil neem. Die woorde wat hier gebesig word - 'hulle was gewillig om Hom in die skuit te neem' - is nie 'n kenmerkende uitdrukking van die Evangelie van Johannes om te sê iemand het tot 
geloof gekom nie. Tog kan dit nie anders verstaan word as geloof en begrip vir die teken nie. Dieselfde woord word gebruik in Johannes 5: 6 waar Jesus ' $n$ sieke na sy geloof vra om gesond te word. In Johannes 5: 35 praat Hy van die gewilligheid om vir'n tyd in die lig van Johannes die Doper te bly. In Johannes 6: 67 word gevra of die dissipels nie gewillig is om van Jesus weg te gaan nie. In Johannes 6: 69 blyk dit dat daar geen sodanige begeerte bestaan nie, want hulle erken Hom as Seun van God. Die bereidheid om Hom in die skuit te neem bestaan nog steeds. Wanneer hulle Jesus in die skuit ontvang, ontvang hulle nie net sy Woord nie, maar Hom as Persoon en is Hy die objek van hulle gelowige aanvaarding: $\mathrm{Hy}$ is al wat hulle het. Na hierdie geloofsaanvaarding word gesê dat die skuit onmiddellik by die land aangekom het. Van der Loos (1968: 126) sê die gebruik van die woord dadelik is kenmerkend by wonderverhale. Dit dui op 'n dringendheid dat die verhaal kan voortgaan noudat die dissipels hulle gewilligheid jeens Jesus betoon het. Die feit dat die skuit so gou by die land aankom, is ' $n$ wonder op sigself en dien as ' $n$ bevestiging van die gebeure op die see (Schnackenburg 1980b: 27).

\section{GEVOLGTREKKING}

Die genre verhaal was die gebruiklike vorm van historiografie in die antieke tyd. Dit beteken nie dat die verhaal niks met die werklike gebeure te doen gehad het nie, maar wel dat dit moeilik is om die presiese gebeure te bepaal omdat die leser nie 'n volledige beskrywing van die gebeure kry nie. Die skrywer gebruik die feit op sy manier om 'n bepaalde punt tuis te bring. Die feite word alleen vanuit één perspektief belig. Of die skrywer se weergawe ipsissima facta et verba daarstel, is onmoontlik om te bepaal. Wat belangriker is, is dat die skrywer só geskryf het om 'n bepaalde doel te bereik.

Hoe word hierdie doel bereik? Deurdat die skrywer eerstens gebruik maak van die instrument van die verteller wat die leser in die verhaal inlei en wat by die leser vertroue inboesem omdat sy getuienis waar is en daarom geglo kan word. Tweedens word dit ook bewerkstellig deur middel van ' $n$ bepaalde vertelpatroon, naamlik die tweestappe-progressie. Die leser word gekonfronteer met twee wonders wat oor dieselfde saak handel, naamlik oor die feit dat die lewe by Jesus Christus te vinde is. Dit word vanuit twee perspektiewe belig: 
- die wonder oor die vermeerdering van die brood word vanuit die perspektief van Jesus vertel; en

- die wonder van die seewandeling word vanuit die perspektief van die dissipels vertel.

Jesus sien 'n skare wat voortdurend na Hom op pad is. Hulle wil iets van Hom hê. Hy is bereid om iets te gee. Die vraag is of dit wat gevra word en dit wat Jesus hulle gee, een en dieselfde ding is. Deur middel van die wonder van die vermeerdering van die brood wys $\mathrm{Hy}$ aan die skare dat $\mathrm{Hy}$ die Brood van die Lewe is: Soos wat Hy genoeg brood aan honger mae kan verskaf, so verskaf $\mathrm{Hy}$ aan mense die Lewe. Soos wat die skare na Hom gestroom het vir aardse verligting van hulle nood, so behoort hulle na Hom te stroom vir' $n$ hemelse gawe wat hulle van 'n ewige nood sal verlos. Die tragiek is dat die skare dit nie kan insien nie. Die vraag is of die dissipels dit insien. Om hierdie vraag te beantwoord, wend die skrywer hom na die tweede wonder. Nou is dit Jesus wat letterlik en figuurlik na die dissipels toe kom. Hy loop op die water na hulle toe gedurende die storm. Soos wat Hy uitkoms bied tydens die storm deur die dissipels dadelik by die land te bring, so bied $\mathrm{Hy}$ as Brood van die lewe ook uitkoms in 'n onstuimige wêreld. En die dissipels besef dit. Hulle was gewillig om Hom in die skuit te neem. Die skrywer het ' $n$ keuse gemaak tussen al die feite en in die proses 'n waarde-oordeel oor die skare en die dissipels uitgespreek: Die skare is verlore omdat hulle hul blindstaar teen hul verwagting van ' $n$ aardse. messias. Dit word bevestig as die skrywer later meld dat hulle van Jesus weggegaan het (Joh 6: 66). Die dissipels daarenteen word gered omdat hulle bereid is om van die Brood van die Lewe te eet: Hulle bly by Jesus omdat hulle sien dat $\mathrm{Hy}$ die woorde van die ewige lewe het en die Heilige van God is (Joh 6: 68-69).

Die gebeure rondom die vermeerdering van die brood en die seewandeling is interpreterend waargeneem en belig. Volledige feite is nie gegee nie, maar in die proses word 'n duidelike boodskap tuisgebring, naamlik dat by Christus lewe is.

\section{Literatuurverwysings}

ARISTOTELES, 1911. The poetics of Aristotle. London: Macmillan.

BARRET, CK 1982. Essays on John. London: SPCK.

BECKER, C 1970. What are historical facts?, in Marsak, LM (ed), The nature of historical inquiry, 35-48. New York: Holt, Rinehart \& Winston.

BROWN, C 1976. History and the believer, in Brown, C (ed), History, criticism and faith, 147-223. Leicester: IVP. 
BROWN, RE 1966. The Gospel according to John New York: Doubleday. The Anchor Bible. BULTMANN, R 1971. The Gospel of John. Oxford: Blackwell.

COETZEE, JC 1976. 'n Pleidooi vir vernuwing in die besondere kanoniek-toegelig aan die hand van die Evangelie van Johannes. Potchefstroom: PU vir CHO.

COETZEE, JC sj a. Besondere kanoniek: Die Evangelie van Johannes. Klasdiktaat, PU vir CHO.

COETZEE, JC sj b Sinoptiese vraagstuk. Klasdiktaat, PU vir CHO.

COLLINGWOOD, RG 1978. Die idea of history. Oxford: Oxford University Press.

DODD, CH 1980. The Fourth Gospel. Cambridge: Cambridge University Press.

DU TOIT, AB 1980. Algemene inleiding tot die Evangelies, in Du Toit, AB (red), Handleiding by die Nuwe Testament, Band 4, 1-30. Pretoria: NG Kerkboekhandel.

FULLER, RH 1971. Interpreting the miracles. London: SCM.

HENDRIKSEN W 1976. NTC: Exposition of the Gospel according to John. Grand Rapids: Baker Book House.

MORRIS, L 1971. Commentary on the Gospel of John. Grand Rapids: Eerdmans.

PIRENNE, H 1970. What are historians trying to do? in Marsak, LM (ed), The nature of historical inquiry, 29-34. New York: Holt, Rinehart \& Winston.

RENGSTORF, K 1971. Semeion, sv TDNT 7, 200-268.

RHOADS, D \& MICHIE, M 1982. Mark as story. Philadelphia: Fortress.

SCHNACKENBURG, R 1980a. The Gospel according to John, I. London: Burns \& Oates.

SCHNACKENBURG, R 1980b. The Gospel according to John, II. London: Burns \& Oates.

SCHNACKENBURG, R 1980c. The Gospel according to John, III. London: Burns \& Oates.

VAN AARDE, AG [1982]. Die vertellersperspektief-analise: 'n Literatuurteoretiese benadering in die eksegese van die evangelies. HTS 38, 58-82.

VAN DER LOOS, H 1968. The miracles of Jesus. Leiden: Brill.

VERSTEEG, JP 1980. Evangelie in viervoud. Kampen: Kok.

VORSTER, WS \& STEYN J 1979. Studiegids NTE 304. Pretoria: Unisa. 